\title{
MOLECULAR TOOLS AND DNA BARCODING FOR CONSERVATION
}

\author{
Guillaume GigOT \\ Jodrell Laboratory, Royal Botanic Gardens, Kew, TW9 3DS Richmond, United Kingdom \\ g.gigot@rbgkew.org.uk
}

KEY WoRDS: Darwin Initiative, biodiversity, conservation

The Darwin Initiative (DI) for the Survival of Species promotes biodiversity conservation and sustainable use of resources around the world (http://www.darwin.gov.uk). The main goal of the DI is to assist countries rich in biodiversity but poor in resources with the conservation of biological diversity and implementation of the Biodiversity Convention. Projects funded under the DI are collaborative, involving either local institutions or communities in the host country in collaboration with a British institution. Here we present four Darwin Initiative projects using molecular tools for species identification, forensic use and conservation:

- the project entitled "Conservation and Monitoring of MesoAmerican orchids" (Ref. 14-001), is based on a partnership between the Lankester Botanica Garden in Costa Rica and the Royal Botanic Gardens Kew in UK.
- the project called "Molecular tools for promoting biodiversity in rainforest fragments of Borneo" (Ref. 10-025), is the result of a collaboration between the Institute of Tropical Biology and Conservation University Malaysia Sabah, the Forest Research Centre Sabah and the Yayasan Sabah and the University of York, the University of Leeds, the Natural History Museum in UK.

- for this project entitled "Certification to support conservation of endangered Mexican desert cacti"(Ref. 14-059), partners come from two universities in Mexico - Universidad Autonoma de Querétaro and Universidad Nacional Autónoma de México (UNAM) - and the University of Reading in UK.

- the project called "Building Genetic Forensic Capacity to reduce South Africa's illegal trade" (Ref. 13-018), involves researchers and students from the University of Kwazulu-Natal in South Africa and University of Sheffield in UK.

Guillaume Gigot was first educated at the University of Montpellier (France) where he studied evolution and ecology. He was then awarded his diploma of engineering in agronomy and environment at "Grande Ecole" in Paris. After working on several research projects in tropical ecology and population genetics in France, he started at the Royal Botanic Gardens, Kew in 2005 as Darwin Initiative Project Officer. He is currently in charge of the coordination and management of a project regarding orchid biodiversity and DNA barcoding in collaboration with the Lankester Botanical Garden in Costa Rica. 